\title{
Preseptal and orbital cellulitis
}

\author{
Emine Akçay, Gamze Dereli Can, Nurullah Çağıl \\ Yıldırm Beyazıt Univ. Medical Faculty Atatürk Training and Research Hospital Dept. of Ophthalmology, Ankara, Turkey
}

\begin{abstract}
Preseptal cellulitis (PC) is defined as an inflammation of the eyelid and surrounding skin, whereas orbital cellulitis (OC) is an inflammation of the posterior septum of the eyelid affecting the orbit and its contents. Periorbital tissues may become infected as a result of trauma (including insect bites) or primary bacteremia. Orbital cellulitis generally occurs as a complication of sinusitis. The most commonly isolated organisms are Staphylococcus aureus, Streptococcus pneumoniae, S. epidermidis, Haempphilus influenzae, Moraxella catarrhalis and S. pyogenes. The method for the diagnosis of OS and PS is computed tomography. Using effective antibiotics is a mainstay for the treatment of PC and OC. There is an agreement that surgical drainage should be performed in cases of complete ophthalmoplegia or significant visual impairment or large abscesses formation.

This infections are also at a greater risk of acute visual loss, cavernous sinus thrombosis, meningitis, cerebritis, endophthalmitis, and brain abscess in children. Early diagnosis and appropriate treatment are crucial to control the infection. Diagnosis, treatment, management and complications of PC and OC are summarized in this manuscript. J Microbiol Infect Dis 2014; 4(3): 123-127
\end{abstract}

Key words: infection, cellulitis, orbita, preseptal, diagnosis, treatment

\section{Preseptal ve Orbital Sellülit}

\section{ÖZET}

Preseptal selülit (PS) göz kapağı ve çevresindeki dokunun iltihabi reaksiyonu iken orbital selülit (OS) orbitayı ve onun içeriğini etkileyen septum arkası dokuların iltihabıdır. Göz çevresi yapılar; travma (sıklıkla böcek ısırığı) veya primer bakteremiye bağlı olarak enfekte olur. Orbital selülit çoğunlukla sinüzite sekonder iltihabi olayın orbita içine ilerlemesiyle oluşur. Sıklıkla kültürlerden üretilen patojenler Staphylococcus aureus, Streptococcus pneumoniae, S. epidermidis, Haempphilus influenzae, Moraxella catarrhalis ve S. pyogenes'dir. Tanıda OS ve PS'yi ayırt etmek için önerilen yöntem bilgisayarlı tomografik görüntülemedir. Uygun antibiyoterapi OS ve PS'de tedavinin ana basamağıdır. Cerrahi drenaj total oftalmopleji, görsel kayıp veya büyük belirgin abse gelişiminde endikedir.

Bu enfeksiyonlar çocuklarda akut görme kaybı, kavernöz sinus trombozu, menenjit, serebrit, endoftalmi, beyin absesi gibi komplikasyonlara neden olabilir. Bu nedenle bu enfeksiyonların erken tanınması ve doğru tedavi edilmesi oluşabilecek ciddi enfeksiyonların önlenmesi açısından çok önemlidir. Bu yazıda PS ve OS'nin tanı, tedavi, yönetim ve komplikasyonları özetlendi.

Anahtar kelimeler: Enfeksiyon, orbita, preseptal, selülit, tanı, tedavi

\section{INTRODUCTION}

Preseptal cellulitis (PC) and orbital cellulitis (OC) are serious infections of the adnexal tissues surrounding the eye. Although they can be seen at any age, children are most commonly affected..$^{1,2}$ If not treated appropriately, they can lead to sight-threatening complications such as acute visual loss and endophtalmitis and life-threatening complications, such as the thrombosis of cavernous sinus, meningitis, cerebritis, and brain abscess. ${ }^{3,4}$ Therefore correct diagnosis and early appropriate treatment is essential.

The purpose of this report is to discuss the predisposing factors, clinical findings, microbiologic data, complications, and efficacy of treatment in PC and $\mathrm{OC}$ in children. 


\section{PATHOGENESIS AND CLASSIFICATION}

Periorbital inflammation is classified according to the severity and its location. The orbital septum divides two parts which the soft tissues of the eyelid (preseptal space) from those of the orbit (postseptal space) (Figure 1). PC is the infection of preseptal space usually originates from trauma, or primary bacteremia. ${ }^{5}$ In OC cases, the infection is localized in the postseptal space and usually occurs as a complication of sinusitis. Generally ethmoid sinusus are predominating as the most common origin. ${ }^{6} \mathrm{Al}-$ though it is penetrated by the neural and vascular structures, the orbital septum preserves entering of the the infectious agents to the back of the orbit. ${ }^{7}$ The veins which drain the orbit, maxillary and ethmoid sinuses and periorbital tissues create an anastomotic network that lack a valve. Hence the venous system allows the spread of infection from one place to another leading to the cavernous sinus involvement. The infection can spread from the transition artery of the ethmoid and frontal bones. ${ }^{6}$

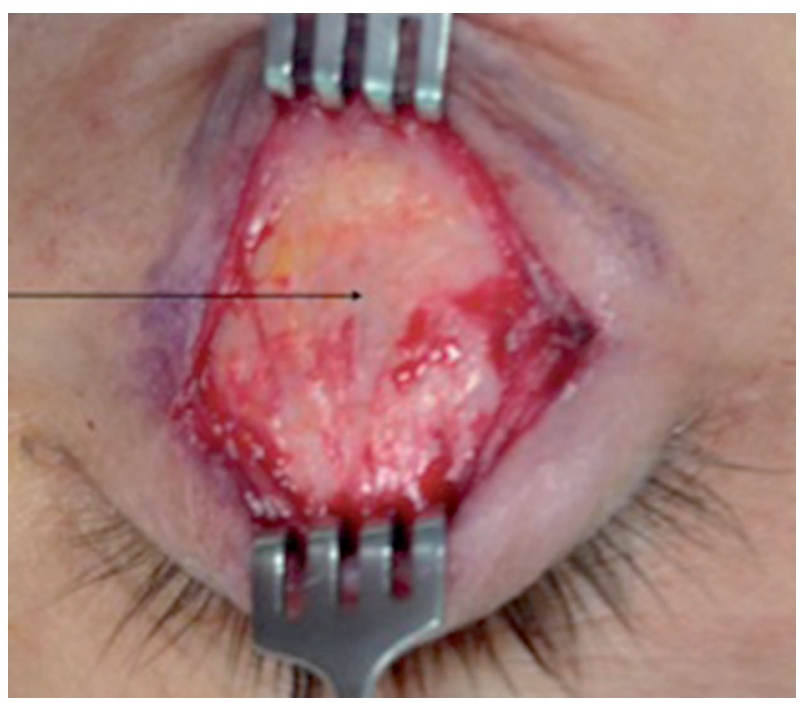

Figure 1. Orbital septum is seen in the picture (arrow) (surgical photograph).

\section{PRESEPTAL CELLULITIS}

Preseptal cellulitis is an infection, which affects the tissue remaining in front of the orbital septum. It is seen more often than $\mathrm{OC}$ and generally is caused by bacteria. ${ }^{8}$ There are two basic mechanisms in the formation of PC. First one is spreading of a local infection to the eyelid. In this process source of infection is penetrating trauma around the eyes or an infection of the skin or subcutaneous tissue (acute dacryocystitis, hordeolum, infected chalazi- on, severe conjunctivitis, impetigo, erysipelas). The other reasons are eye surgery or insect bites. In the second mechanism it is originated from the focus of infection, which is far from orbit. General condition, co-morbidities of the patient as well as the anamnesis and physical examination are important clues to determine the source of the infection. ${ }^{4}$

\section{Etiology}

Preseptal cellulitis is generally seen in children especially those that are 3-7 years old. ${ }^{9}$ Bacteremia has been reported in approximately $80 \%$ of children diagnosed with periorbital cellulitis. ${ }^{10} \mathrm{H}$. influenzae has been associated with preseptal cellulitis in children below the age of 4 years. In 1985 after the introduction of $\mathrm{H}$. influenzae vaccine the microbiological spectrum of bacterial periorbital cellulitis has changed. ${ }^{10,11}$ Recent retrospective studies showed the decreasing incidence of $H$. influenzae in periorbital cellulitis. ${ }^{12}$ Currently S. aureus and Streptococcus species are the predominanting microorganisms as the cause of PC. ${ }^{11}$ Among the etiologic agents causing preseptal cellulitis in children older than 4 years, S. aureus, S. epidermidis, S. pneumoniae, mixed anaerobic-aerobic bacterial flora seem to be the leading microorganisms. ${ }^{13,14}$

\section{Clinical findings and diagnosis}

Preseptal cellulitis is clinically characterized by erythema, edema, and/or warmth of the periorbital tissues. High fever, fatigue and loss of appetite are determined especially in children. Clinical signs of orbital soft tissue involvement are not visible in PC. ${ }^{5}$

Preseptal cellulitis diagnosis is made by clinical examination and it is the most valuable thing in the differential diagnosis of PC. ${ }^{5}$ Various situations can mimic PC. Some of these are; OC, idiopathic orbital inflammatory disease, thyroid orbitopathy, orbital trauma, allergic contact dermatitis, acute adnexal infections, posterior scleritis, endophthalmitis, granulomatous vasculitic autoimmune diseases and tumoral metastases. ${ }^{6}$

In PC imaging with computed tomography (CT) is based on the clinical examination. If there is afferent pupillar defect, limitation of extraocular movements or pain exists, CT must be carried out. Also if the examination is difficult, CT should be done. Axial and coronal sections of the orbit and sinuses should be fine visualised for diagnosis. ${ }^{1}$

\section{Treatment}

The management of PC is mainly based on medical treatment, surgical approach is usually not neces- 
sary. The children under 1 year of age should be follow up in the hospital. As the origin of the possible infection might be upper respiratory tract and sinuses, initial empiric antibiotic therapy should cover the flora there. If there is a focal trauma, treatment should include $S$. aureus. Outpatient treatment with first generation cephalosporin, amoxicillin-clavulanic acid or ceftriaxone is suitable for mild cases of older children. If there is no response to the treatment in 48-72 hours, intravenous therapy must be applied. In young children and severe cases, intravenous treatment and close observation in hospital is required. Using the second or third generation cephalosporins and penicillinase-resistant penicillins is important. If anaerobes plus $S$. aureus is suspected clindamycin + cephalosporin treatment can be an option. Chloramphenicol can be used in patients allergic to penicillin. An additional one day follow up will be suitable after achieving clinical improvement within 48-72 hours of antibiotic therapy. The total treatment must be completed 14 days with oral antibiotics. If the eyelid abscess is present, drainage of the abscess has to be done as well. ${ }^{12}$

\section{Complications}

Meningitis is the most important complication of PC especially in children who have $\mathrm{H}$. influenza cellulitis secondary to bacteremia. ${ }^{15}$

\section{ORBITAL CELLULITIS}

Orbital cellulitis is a serious infection of the posterior tissues to the orbital septum. Serious complications such as intracranial abscess, meningitis, carotid artery occlusion, cavernous sinus thrombosis, and visual loss can be observed. ${ }^{16}$ It leads to a more severe infection than $\mathrm{PC}$. The most common underlying factor for its development is a preceding ethmoid sinusitis and the microbiology of $\mathrm{OC}$ and abscess tends to reflect the underlying sinus involvement and pathology. ${ }^{5}$ As the medial part of the orbit is very thin and due to its porous structure infections can extend easily to the neighborhood structures. ${ }^{16}$ Furthermore, venuos system itself may one of the other reason of the spreading of the infection as the lack of valve system of venos system in this reagion. ${ }^{16}$ Also there are some exogenous and endogenous causes of OC. Blunt or penetrating trauma of the orbita , the surgery of orbital and periorbital, structures and dental procedures are some examples for exogenous causes. ${ }^{16}$ Septisemi and endophtalmitis are the examples for endogenous causes of OC. ${ }^{16}$
Chandler proposed a clinical classification which separates the orbital complications of acute sinusitis into 5 groups (Table 1). ${ }^{17}$

Table 1. Orbital complications of acute sinusitis. Chandler classification

\section{Groups}

Group 1: Preseptal cellulitis

Group 2: Orbital cellulitis

Group 3: Subperiosteal abscess

Group 4: Intraorbital abscess

Group 5: Cavernous sinus thrombosis

\section{Etiology}

Group A beta-hemolytic streptococci, S. aureus, $S$. pneumoniae, $H$. influenzae, $M$. catarrhalis, other streptococcal species, and anaerobic microorganisms are the micrororganisms which are responsible for $\mathrm{OC}$ in pediatric patients. ${ }^{18,19}$ In the pre- $H$. influenzae type $B$. vaccine era, $H$. influenzae type $B$ was the predominant organism isolated in children with positive blood cultures; it represented $15 \%$ to $82 \%$ of all isolates depending on the patient population..$^{20}$ Today, Streptococcus species are the leading microrganisms responsible for the OC. ${ }^{20}$ Recent studies demonstrate that Staphylococcus and Streptococcus species are the most common pathogens of the pediatric OC. In some population methicillin-resistant $S$. aureus is the increasing species responsible for pediatric OC. ${ }^{21}$

\section{Clinical findings and diagnosis}

Cinical findings of $O C$ are pain, vision loss, restricted motility, exophthalmus, proptosis and diplopia (Figure $2 \mathrm{~A}) .{ }^{12}$ Vision loss can be a seen as a complication of involvement of optic nerve and retina due to orbital compartment syndrome, vascular infiltration, mass effect and optic neuritis. ${ }^{18}$

Because of lack of orbital signs and symptoms in preseptal celulitis, this diagnosis can easily be excluded. Mycotic OC, neoplasms thyroid eye disease (Graves ophtalmopathy) and idiopathic orbital inflammation should be considered in the differential diagnosis of bacterial OC. Systemic autoimmune congenital and traumatic disease can also mimmic OC. ${ }^{16}$

After clinical examination, complete blood count, blood cultures and computed tomography 
should be performed for clinical staging. Contrast agents should be used during CT imaging if it is possible. Because it can increase the sensitivity and spesifity of diagnosis of OC. Postseptal inflamation may be diffuse or localised in bacteriaal OC: In abscess formation localized involvement can be seen intra or extraconal region. Subperiostaeal abscess formation is an other complication which originates between the bone and periorbita. CT images shows localized inflammation in this abscess formation. ${ }^{22}$

\section{Treatment}

The proper use of antibiotics is crucial in the treatment of PC and OC. Improvement can be achieved in clinical signs (Figure 2B). The general acceptance of $S$. pneumoniae, S. aureus, other streptococci, and non-spore-forming anaerobes as the main causative agents indicates the most appropriate antibiotic regimen. ${ }^{16}$ It is reasonable to use ampicillin-sulbactam for the initial empiric therapy. ${ }^{5}$ Other options may include nafcillin for Staphylococcus or Streptococcus species. Clindamycin can be used for $S$. pneumoniae, S. aureus, and anaerobes, and cefotaxime for Gram negative organisms, nontypeable $H$. influenzae, Moraxella, and resistant pneumococci. Most experts recommend that children younger than 12-15 months with signs of systemic illness can be follow up in the hospital for parenteral therapy. In patients with OC, intravenous ampicillin-sulbactam therapy for initial 24-48 hours seems reasonable, keeping in mind that this regimen may require reevaluation. ${ }^{23}$ Surgical drainage followed by antibiotic therapy is mainstay in the presence of subperiosteal or intraorbital abscess. ${ }^{23}$

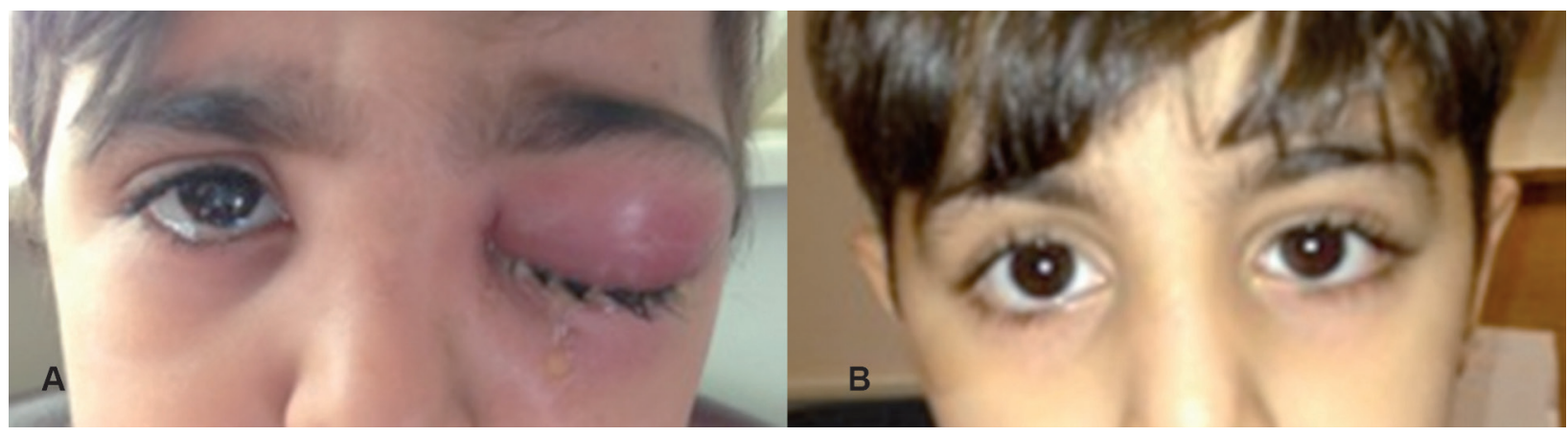

Figure 2. Ten years old patient with orbital cellulitis.

A-The first clinical examination. Edema, hyperemia and total ptosis seen in the left upper eyelid and periocular region B-After medical treatment. Improved clinical findings are seen in the picture

\section{Complications}

Systemic or local complications of OC were reported in the literature. Ocular complications may include corneal disease, retinitis, uveitis, exudative retinal detachment, optic neuropathy, endophthalmitis, and globe rupture. A motility defect, intracranial disease, cavernous sinus thrombosis, meningitis, sepsis, brain abscess are some of the catastrophic complications of OC which can lead to death. $3,4,8,16,19,22,25$

\section{CONCLUSION}

Cellulitis of the orbital region in children, localized in front of the orbital septum, is a disease with a low risk of complications, provided that the patients are subjected to proper medical treatment. However, the possibility of an extension of the inflammation in the retroseptal area makes multidisciplinary management necessary in order to achieve cure and minimize risk for an adverse visual defect. OC can cause serious ocular and neurological complications. ${ }^{26}$ Timely and appropriate use of imaging modalities, antimicrobial therapy and surgery can lead to better outcomes. ${ }^{27}$

\section{REFERENCES}

1. Handler LC, Davey IC, Hill JC, Lauryssen C. The acute orbit: differentiation of orbital cellulitis from subperiosteal abscess by computerized tomography. Neuroradiology 1991;33:1518.

2. Schramm VL Jr, Curtin HD, Kennerdell JS. Evaluation of orbital cellulitis and results of treatment. Laryngoscope 1982;92:732-738.

3. Krohel GB, Krauss HR, Winnick J. Orbital abscess presentation, diagnosis, therapy and sequelae. Ophthalmology 1982;89:492-498.

4. Lessner A, Stern GA. Preseptal and orbital cellulitis. Infect Dis Clin North Am 1992;6:933-952. 
5. Givner LB. Periorbital versus orbital cellulitis. Pediatr Infect Dis J 2002;21:1157-1158.

6. Wald ER. Periorbital and orbital infections. In: Long SS, Pickering LK, Prober CG, eds. Principles and Practice of Pediatric Infectious Diseases, 2nd ed. New York: Churchill Livingstone; 2003:508-513.

7. Coats DK, Carothers TS, Brady-McCreery K, Paysse EA. Ocular Infectious Diseases. In: Feigin RD, Cherry JD, et al. eds. Textbook of Pediatric Infectious Diseases. 5th ed. Philadelphia: WB Saunders Company; 2004;790-792.

8. Ambati BK, Ambati J, Azar N, et al. Periorbital and orbital cellulitis before and after the advent of Haemophilus influenza type B vaccination. Ophthalmol 1986;14:211-219.

9. Van Dissel JT, de Keizer RJW. Bacterial infections of the orbit. Orbit 1998;17:227-35.

10. Schwartz GR, Wright SW. Changing bacteriology of periorbital cellulitis. Ann Emerg Med. 1996;28:617-620.

11. Donahue SP, Schwartz G. Preseptal and orbital cellulitis in childhood. A changing microbiologic spectrum. Ophthalmology. 1998;105:1902-1905. discussion 1905-1906.

12. Botting AM, Mclntosh D, Mahadevan M. Paediatric pre- and post-septal peri-orbital infections are different diseases: A retrospective review of 262 cases. Int J Pediatr Otorhinolaryngol. 2008;72:377-383.

13. Rubinstein JB, Handler SD. Orbital and periorbital cellulitis in children. Head Nck Surg 1982;5:15-22.

14. Chaudhry IA, Shamsi FA, Elzaridi E, et al. Inpatient preseptal cellulitis: experience from a tertiary eye care centre. $\mathrm{Br} J$ Ophthalmol 2008 ;92:1337-1341.

15. Steinkuller PG, Jones DB. Preseptal and orbital cellulitis and orbital abscess. In:Linberg JV, Oculoplastic \& Orbital Emergencies. Noorwalk: Appleton \& Lange, 1990:51-66.
16. Jain A, Rubin PA. Orbital cellulitis in children. Int Ophthalmol Clin. 2001;41:71-86.

17. Chandler JR, Langenbrunner DJ, Stevens ER. The pathogenesis of orbital complications in acute sinusitis. Laryngoscope. 1970;80:1414-1428.

18. Kloek CE, Rubin PA. Role of inflammation in orbital cellulitis. Int Ophthalmol Clin. 2006;46:57-68.

19. Nageswaran S, Woods C, Benjamin D, et al. Orbital cellulitis in children. Pediatr Infect Dis J. 2006;25:695-699.

20. Barone SR, Aiuto LT. Periorbital and orbital cellulitis in the Haemophilus influenzae vaccine era. J Pediatr Ophthalmol Strabismus 1997;34:293-296.

21. McKinley SH, Yen MT, Miller AM, Yen KG. Microbiology of pediatric orbital cellulitis. Am J Ophthalmol 2007;144:497-501.

22. Eustis HS, Mafee MF, Walton C, Mondonca J. MR imaging and CT of orbital infections and complications in acute rhinosinusitis. Radiol Clin North Am. 1998;36:1165-1183.

23. Goldman RD, Dolansky G, Rogovic AL. Predictors for admission of children with periorbital cellulitis presenting to the pediatric emergency department. Pediatr Emerg Care 2008;24:279-283.

24. Teele DW. Management of the child with red and swollen eye. Pediatr Infect Dis J 1983;2:258-262.

25. Primeggia J, Cyriac G, Kumar P. Invasive orbital aspergillosis in an apparently immunocompetent host without evidence sinusitis. J Microbiol Infect Dis 2012;2:113-116.

26. Georgakopoulos CD, Eliopoulou MI, Stasinos S, et al. Periorbital and orbital cellulitis: a 10-year review of hospitalized children. Eur J Ophthalmol 2010;20:1066-1072.

27. Uy HS, Tuano PM. Preseptal and Orbital Cellulitis in a Developing Country. Orbit 2007;26:33-37. 